\title{
PELATIHAN PENINGKATAN KOMPETENSI GURU MTSN 1 KOTA PAYAKUMBUH DALAM PENGEMBANGAN MEDIA PEMBELAJARAN TERINTEGRASI TIK
}

\author{
Dilson $^{1}$, Noviardi ${ }^{2}$, Lilik Suhery ${ }^{3}$, Hanifah Asnur ${ }^{4}$, Rini Yunita ${ }^{5}$, Siska Arimadona ${ }^{6}$ \\ ${ }^{12345}$ Sekolah Tinggi Teknologi Payakumbuh, Indonesia \\ ${ }^{6}$ STKIP Ahlussunnah Bukittinggi, Indonesia \\ 1dilsonpyk2013@gmail.com
}

\begin{abstract}
The difficulty of designing a meaningful integrated ICT learning media that meets the quality standards of instructional media was a problem faced by teachers in the field of study. Purpose of activities were to train teachers of MTSN 01 Kota Payakumbuh to have the ability (pedagogy) in designing learning media (content) using information and communication technology (ICT). Community service activities were carried out in 3 (three) stages, namely, presentation of material with questions and answers, work practices, and evaluation. Based on observations during practical work, teachers have understood the steps in designing ICT integrated learning media. The teacher enthusiasm to ask questions in completing the media was seen when identifying ICT devices, teaching materials searching using the internet and compiling the media into Ms.Powerpoint. From the 64 questionnaire sheets that were distributed and analyzed quantitatively, it was found that $53,125 \%$ of the teachers stated that the training was categorized as good, 37.5\% stated that they were lacking, and 9,375\% stated that they were very poor. Although more than $1 / 2$ of the training participants stated that they were satisfied with the training implemented, there were still some weaknesses in the initial planning (group division and preparation of lesson plans), as well as the training process (lack of time to discuss the results of the participants' practical work). By adding time duration and dividing groups based on productive age with unproductive age, training using input, process and output methods can improve pedagogical competence in designing meaningful learning media in the learning process.
\end{abstract}

Keywords: Training; Media Learning; Information and communication technology; Pedagogy

\begin{abstract}
Abstrak
Sulitnya merancang media pembelajaran terintegrasi TIK secara bermakna yang memenuhi standar kualitas media pembelajaran merupakan permasalahan yang dihadapi oleh guru-guru bidang studi. Tujuan kegiatan adalah melatih guru bidang studi MTsN 01 Kota Payakumbuh agar memiliki kemampuan (pedagogi) dalam merancang media pembelajaran (konten) menggunakan teknologi informasi dan komunikasi (TIK). Kegiatan pengabdian dilakukan 3 (tiga) tahap yaitu, pemaparan materi dan tanya jawab, praktik kerja, dan evaluasi. Berdasarkan pengamatan selama praktik kerja, guru-guru telah memahami langkah-langkah dalam merancang media pembelajaran terintegrasi TIK. Antusias guru bertanya dalam menyelesaikan media terlihat pada saat melakukan identifikasi perangkat TIK, pencarian materi ajar menggunakan internet dan pada saat menyusun media kedalam Ms. Powerpoint. Dari 64 lembar angket yang disebar dan dianalisa secara kuantitatif, diketahui $53.125 \%$ guru menyatakan pelatihan yang dilakukan dikategorikan baik, $37.5 \%$ menyatakan kurang, dan $9.375 \%$ menyatakan sangat kurang. Meskipun lebih dari $1 / 2$ dari peserta pelatihan menyatakan puas dengan pelatihan yang dilaksanakan, tetapi masih terdapat beberapa kelemahan dalam perencanaan awal (pembagian kelompok dan persiapan RPP), serta proses pelatihan (kurangnya waktu diskusi hasil praktik kerja peserta). Dengan menambahkan durasi waktu dan membagi kelompok berdasarkan usia produktif dengan usia tidak produktif, maka pelatihan menggunakan metode input, proses dan output ini dapat meningkatkan kompetensi pedagogik dalam merancang media pembelajaran yang bermakna dalam proses pembelajaran.
\end{abstract}

Kata kunci: pelatihan; media pembelajaran; teknologi informasi dan komunikasi; pedagogi 


\section{Pendahuluan}

Perkembangan Tekonologi Informasi dan Komunikasi (TIK) dalam beberapa dekade terahir berjalan sangat cepat. Pada satu sisi perkembangan ini menjadi solusi bagi dunia pendidikan baik tingkat SD, SLTP, SLTA dalam mengakses berbagai informasi. Namun disisi lain hal ini menuntut kemampuan profesional guru untuk menguasai pemanfaatan TIK dalam mendukung pelaksanaan kegiatan pembelajaran. Keberhasilan pembelajaran merupakan tanggung jawab guru secara profesional(Sudratjat, 2020), oleh sebab itu seorang guru harus menguasai dua pengetahuan dalam melakukan pembelajaran secara seimbang, yaitu pengetahuan materi pelajaran dan pengetahuan pedagogik(Wulandari \& Iriani, 2018). Untuk melaksanakan kompetensi pedagogik, guru dituntut memiliki kemampuan secara metodologis dalam hal perancangan dan pelaksanaan pembelajaran, termasuk didalamnya penguasaan penggunaan teknologi pada media pembelajaran(Muslih, 2016).

Integrasi teknologi secara bermakna dalam pembelajaran bukanlah hal yang mudah bagi guru. Agar dapat memilih teknologi yang tepat, seorang guru harus menguasai materi yang akan diajarkan (Sholihah \& Yuliati, 2016) sehingga dapat menganalisis karakter dari suatu materi pembelajaran. Selain itu, seorang guru juga harus mempertimbangkan untuk memilih strategi mengajar yang sesuai dengan teknologi yang digunakan, termasuk pada pengetahuan pedagogi (Isma Nastiti Maharani, 2016). Sehingga untuk dapat mengintegrasikan teknologi dengan baik, guru harus menguasai pengetahuan konten materi pembelajaran, pedagogi, dan teknologi. Ketiga pengetahuan tersebut saling berinteraksi dan beririsan membentuk Technological Pedagogical Content Knowledge (TPACK)(Koehler et al., 2013).

Kegiatan pengabdian dilakukan di MTsN 1 Kota Payakumbuh yang berjarak $6 \mathrm{Km}$ dari Sekolah Tinggi Teknologi Payakumbuh (STTP). Beberapa permasalahan yang dihadapi oleh guru-guru MTSN 1 Kota Payakumbuh menurut paparan Wakil Kepala bagian Kurikulum adalah kurangnya pemahaman guru tentang penggunaan perangkat TIK (perangkat keras maupun perangkat lunak) dalam membuat media pembelajaran(Isma Nastiti Maharani, 2016). kurangnya pelatihan dalam upaya meningkatan profesionalisme guru untuk mengembangkan media pembelajaran (Hudiono, 2013), Disamping itu guru juga kesulitan menerapkan metode yang cocok dalam mengajar(Arsyad, 2016). Guruguru tidak memiliki cukup waktu untuk mengembangkan kemampuannya, karena disibukkan dengan kegiatan administrasi dan kegiatan masing-masing.

Berdasarkan permasalahan yang ada, sejalan dengan salah satu dari empat prinsip pembelajaran sesuai amanat standar proses 65 tahun 2013 yaitu pemanfaatan teknologi informasi dan komunikasi untuk meningkatkan efisiensi dan efektivitas pembelajaran, maka Tim Pengabdian Kepada Masyarakat (PKM) STTP menawarkan solusi agar diadakan pelatihan pengembangan dan perancangan media pembelajaran terintegrasi TIK menggunakan aplikasi Ms. Powerpoint 2013. Alasan pengabdi memilih pelatihan ini adalah agar dapat menumbuh kembangkan kreativitas guru dalam merancang dan mengembangkan media pembelajaran, meningkatkan strategi pembelajaran klasik melalui belajar bagaimana menggunakan teknologi, infusing technology untuk memfasilitasi pembelajaran melalui pemahaman bagaimana dan kapan mengintegrasikan teknologi. Selain itu pemanfaatan TIK dalam pembelajaran akan 
memberikan kesempatan kepada guru untuk merancang pengalaman belajar yang bermakna dengan menggunakan teknologi.

\section{Metode}

Kegiatan pengabdian yang dilakukan di MTsN 1 Kota Payakumbuh adalah pelatihan peningkatan kompetensi guru dalam merancang dan mengembangkan media pembelajaran terintegrasi TIK. Pelatihan dilakukan selama 2 (dua) hari yaitu pada hari jumat dan sabtu tanggal Juni 2020 melibatkan 4 kelompok guru bidang studi yaitu kelompok bahasa, IPA, IPS, dan PAI. Durasi pelatihan $2 \frac{1}{2}$ jam untuk tiap kelompok bidang studi. Jumlah guru yang dilatih adalah 64 orang dengan rincian 16 orang kelompok IPS, 15 orang kelompok bahasa, penjaskes, 14 orang kelompok IPA, dan 19 orang kelompok PAI. Sarana pelatihan menggunakan labor komputer MTsN 1 Kota Payakumbuh. Bahan-bahan berupa teks, gambar, suara, dan video disediakan oleh pengabdi dan diserahkan kepada peserta pelatihan untuk kebutuhan pelatihan.

Menggunakan metode Input, Proses dan Output, kegiatan PKM dilakukan 3 (tiga) tahap, yaitu 1) tahap pemaparan dan pembagian materi dalam bentuk modul, 2) praktek kerja melalui studi kasus, dan 3) Evaluasi seperti terlihat pada gambar 1 berikut :

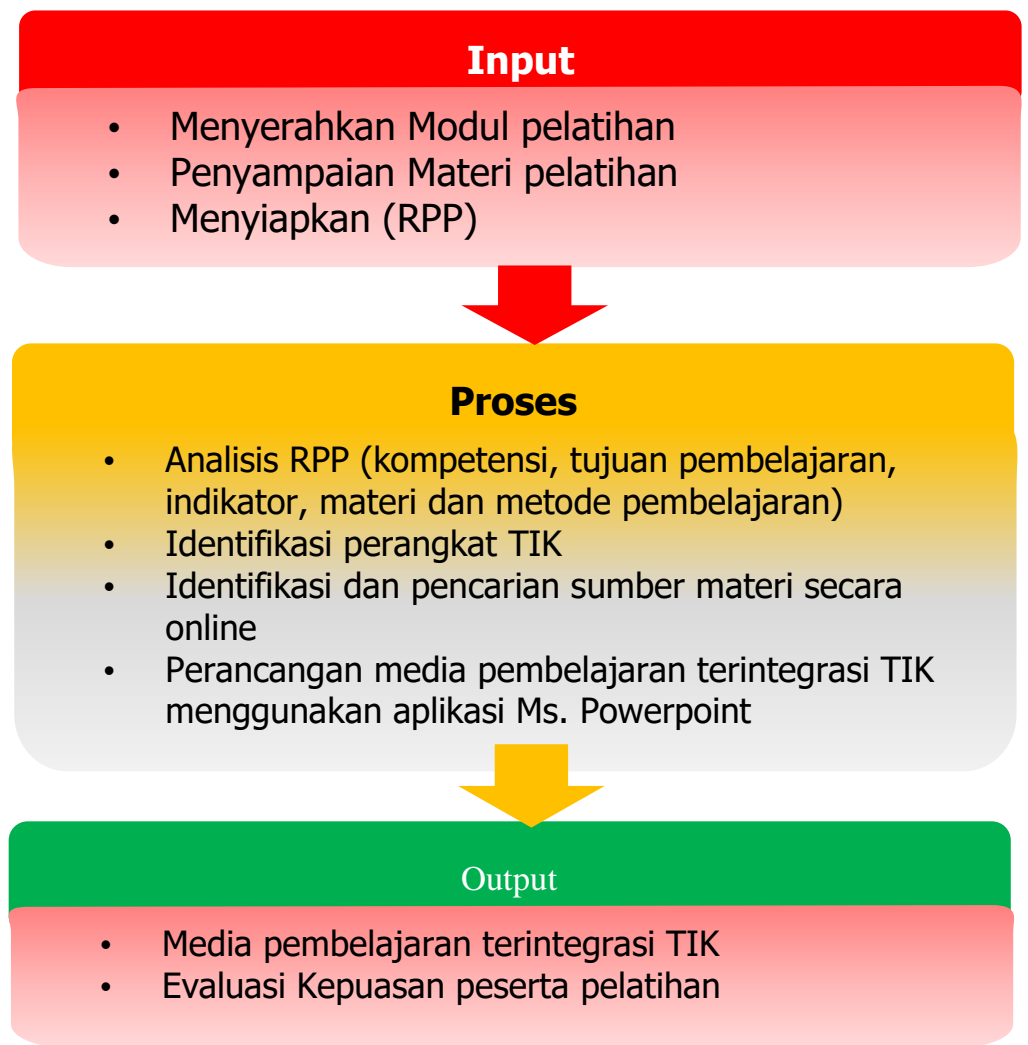

Gambar 1. Tahapan Pengabdian Kepada Masyarakat

Pada tahap input, tim pengabdi membagikan softcopy modul dan bahan pelatihan kepada peserta pelatihan dibantu oleh dosen pendamping, narasumber memaparkan materi-materi pokok yang akan dilaksanakan selama pelatihan. Narasumber juga mengingatkan guru bahwa tidak semua sumber belajar digital dapat mendukung 
pembelajaran. Rancangan pelaksanaan pembelajaran (RPP) berbasis TIK perlu disesuaikan dengan tujuan kurikulum. Dengan demikian, menjadi tuntutan bagi guru supaya bisa menggunakan aplikasi komputer dengan tepat jika menginginkan proses pembelajaran yang lebih bermakna.

Pada tahap proses, narasumber dan dosen pendamping memandu guru melakukan identifikasi perangkat TIK dan sumber materi pembelajaran baik secara offline maupun online. Agar proses pembelajaran terlaksana, guru harus merancang pembelajaran dengan menggunakan TIK sesuai dengan prinsip pembelajaran. Oleh sebab itu guru dapat menggunakan sumber belajar untuk memperkenalkan suatu topik pembelajaran. Topik yang dijadikan sebagai studi kasus dalam praktik kerja adalah RPP Guru kelas VII, Matapelajaran IPA semester Ganjil dengan topik "Klasifikasi Mahluk Hidup". Pendekatan yang digunakan dalam pelatihan menyusun RPP terintegrasi TIK ini adalah 1) pendekatan idealis (theme-centered approach); dan 2) pendekatan software (software-centered approach) (Nurhayati, 2018). Agar memenuhi standar kualitas media pembelajaran, maka pengabdi membuatkan pedoman dalam bentuk hirarki untuk memudahkan peserta dalam merancang media pembelajaran terintegrasi TIK seperti gambar 2 berikut.

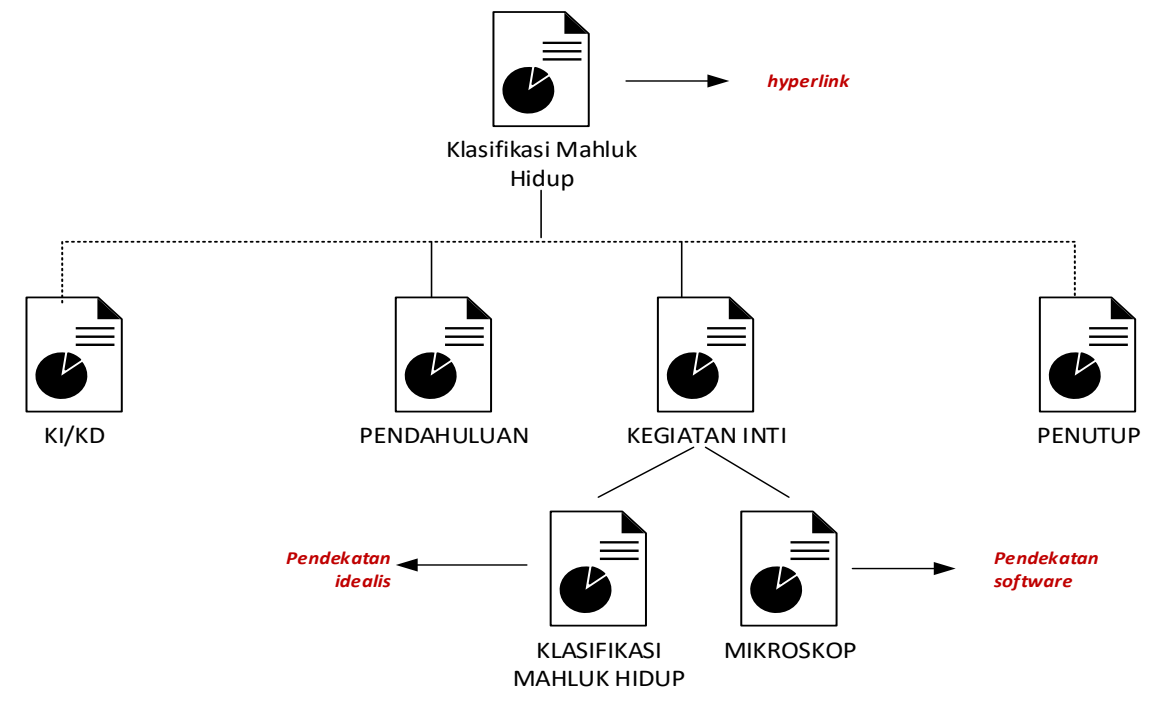

Gambar 2. Rancangan hirarki media pembelajaran terintegrasi TIK

Output yang dihasilkan dari kegiatan pengabdian berupa project pelatihan media pembelajaran. Sedangkan outcome yang diharapkan berupa pemahaman dan kepuasan peserta pelatihan, dilakukan dengan cara pengamatan dan evaluasi menggunakan angket. Untuk mengukur tingkat pemahaman dan kepuasan peserta pelatihan dilakukan dengan cara menyebarkan angket yang memuat 4 pokok kegiatan yang akan dievaluasi, yaitu (1) pemaparan materi, (2) isi materi dan tanya jawab, dan (3) praktik kerja.

Analisis data secara kuantitatif dilakukan menggunakan skala likert. Skala Likert dapat digunakan untuk mengukur sikap, pendapat, dan persepsi seseorang atau sekelompok orang tentang fenomena sosial(Lungit Wicaksono, 2020). Skore dan kategori yang yang digunakan untuk mengukur kepuasan guru terhadap pelatihan yang dilaksanakan oleh tim PKM STTP adalah 1=Tidak baik , 2=kurang baik, 3=cukup, 4=baik, 
dan $5=$ baik sekali. Skor penilaian masing-masing guru diperoleh dengan menggunakan rumus berikut :

$$
\text { Skor }=\frac{\text { Skor yang diperoleh }}{\text { Skor Maksimal }} \times 100 \%
$$

Setelah ditentukan skor dari masing-masing guru, maka berikutnya adalah menentukan rata-rata kelas (yaitu skor yang diperoleh semua guru) dan menentukan standar deviasinya. Dari rata-rata kelas $(\bar{x})$ dan standar deviasi $(S D)$ ditentukan kategori respon guru terhadap pelatihan seperti dijelaskan pada tabel 1 berikut :

Tabel 1. Kategori respon guru

\begin{tabular}{ll}
\hline Nilai & Kategori \\
\hline$x \geq \bar{x}+1 . S D$ & Sangat baik \\
$\bar{x}+1 . S \mathrm{D} \geq x>\bar{x}$ & Baik \\
$\bar{x}>x \geq \bar{x}-1 . S D$ & Kurang \\
$x<\bar{x}-1 . S D$ & Sangat Kurang \\
\hline
\end{tabular}

Dari skor yang diperoleh akan diinterpretasikan secara kualitatif untuk menjelaskan makna dari skor yang diperoleh

\section{Hasil dan Pembahasan}

1. Pemaparan Materi (Input)

Pemaparan berupa pokok-pokok materi penting dilakukan selama 15 menit menggunakan slide powerpoint. Materi yang dipaparkan adalah a) pertimbangan dalam memilih dan menentukan teknologi pembelajaran yang tepat, b) Mengetahui jenis-jenis materi pembelajaran (fakta, konsep, prinsip/kaidah, prosedur), c) Kriteria yang harus diperhatikan dalam memilih media pembelajaran, d) pendekatan/model yang tepat dalam pemilihan proses pembelajaran, e) prosedur yang digunakan dalam memilih media pembelajaran, f) identifikasi dan pemilihan media pembelajaran berdasarkan perangkat TIK yang dibutuhkan, g) identifikasi dan pemilihan sumber belajar berbasis TIK untuk pembelajaran, h) pengumpulan data/sumber materi ajar (multimedia) dari internet, i) integrasi TIK dalam media pembelajaran, dan j) perancangan media pembelajaran terintegrasi TIK menggunakan Ms. Powerpoint 2013.

Pada saat pemaparan materi, narasumber memandu peserta untuk fokus pada pembahasan materi identifikasi perangkat TIK yang akan digunakan, dan menganalisa RPP serta mengintegrasikannya kedalam proses kegiatan pembelajaran. Sambil membaca dan memahami materi yang tersedia di dalam modul, peserta dapat bertanya kepada tim pengabdi jika ada langkah-langkah pada modul yang kurang dipahami. Waktu yang diberikan kepada peserta untuk menganalisis aktivitas pembelajaran yang terintegrasi TIK pada RPP serta tanya jawab adalah 15 menit. 


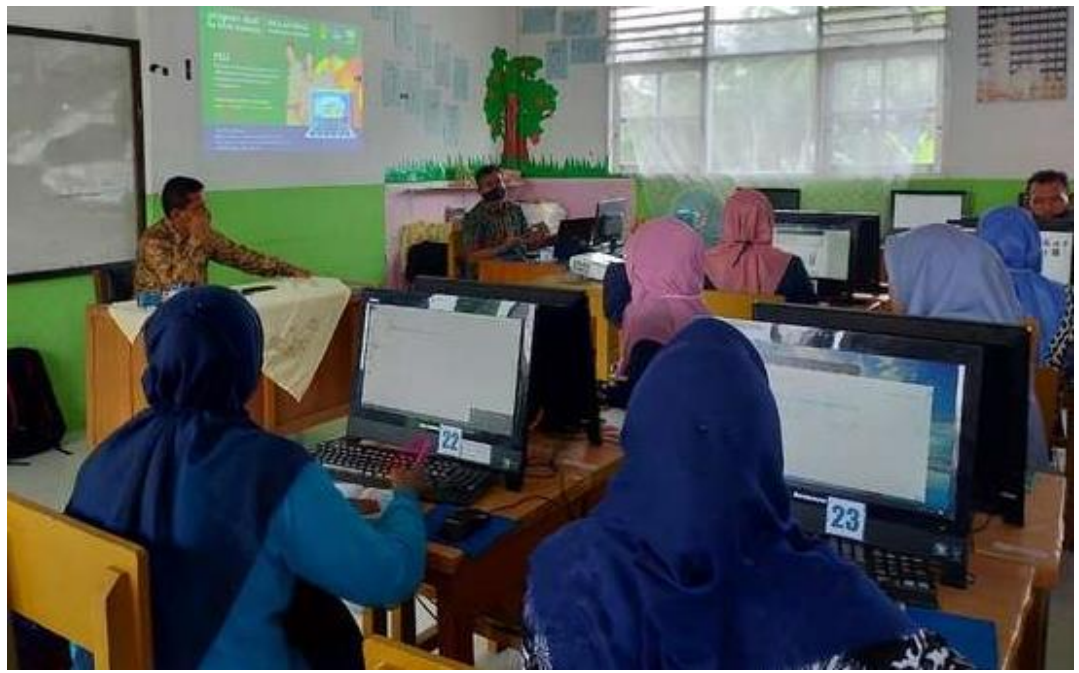

Gambar 3. Pemaparan pokok materi pelatihan

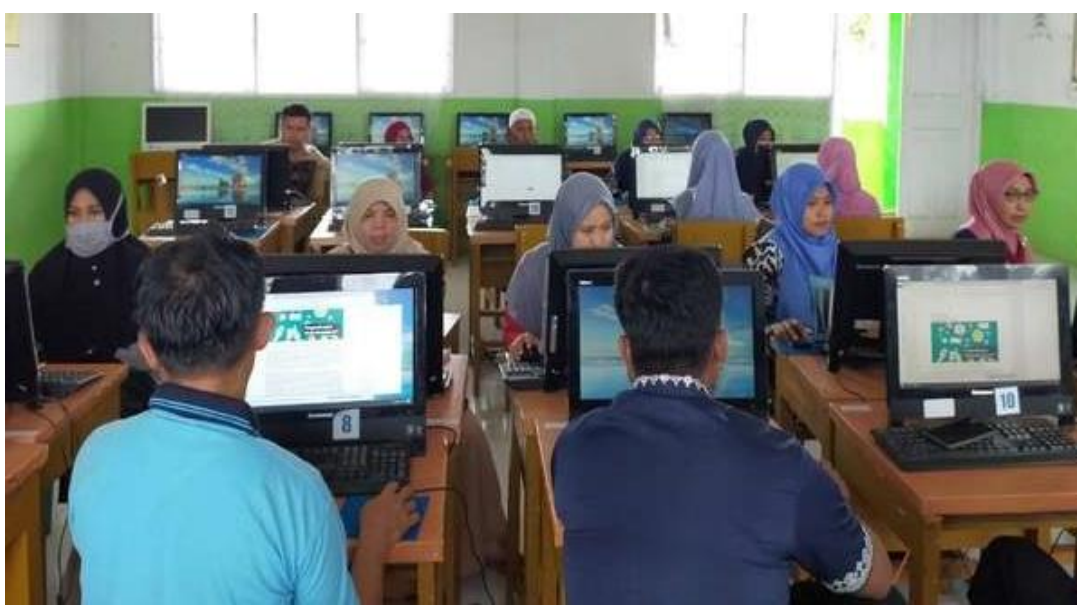

Gambar 4. Peserta membaca modul pelatihan

\section{Praktik Kerja}

Setelah guru-guru mendengarkan dan membaca modul tentang tahapan-tahapan yang harus dilakukan dalam pengembangan media pembelajaran terintegrasi TIK, kegiatan selanjutnya adalah praktik kerja. Agar tujuan pelatihan tercapai, maka tim pengabdi memilih teknik pemecahan masalah study kasus dalam pelaksanaan praktik kerja. Menurut (Nursita, Darsikin, 2016) kemampuan pemecahan masalah adalah kemampuan individu dalam menggunakan proses berpikir untuk memecahkan permasalahan melalui pengumpulan fakta-fakta, analisis informasi, menyusun berbagai alternatif pemecahan, dan memilih pemecahan yang paling efektif.

Kegiatan yang dilakukan selama praktik kerja adalah mendampingi guru a) dalam mencari sumber materi (berupa gambar, teks, suara, atau video) secara online, b) merancang media pembelajaran terintegrasi TIK sesuai dengan standar kualitas media pembelajaran (terstruktur, memuat mode representasi pesan ajar dengan multimedia, mudah dibaca, jelas, animasi sesuai dengan tujuan, memiliki hyperlink, dan memiliki unsur kreatif dan inovatif) menggunakan aplikasi Ms. Powerpoint 2013. Untuk menghemat waktu pelatihan, maka perancangan media pembelajaran menggunakan template yang sudah disediakan oleh tim pengabdi STTP. 


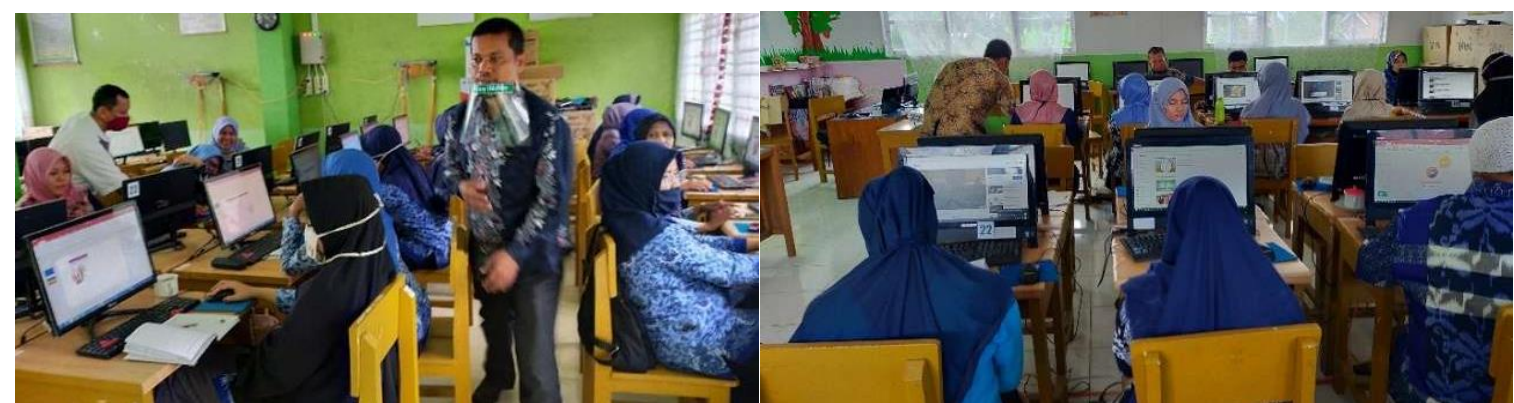

Gambar 5. Peserta pelatihan mencari sumber materi di Internet sesuai kebutuhan RPP

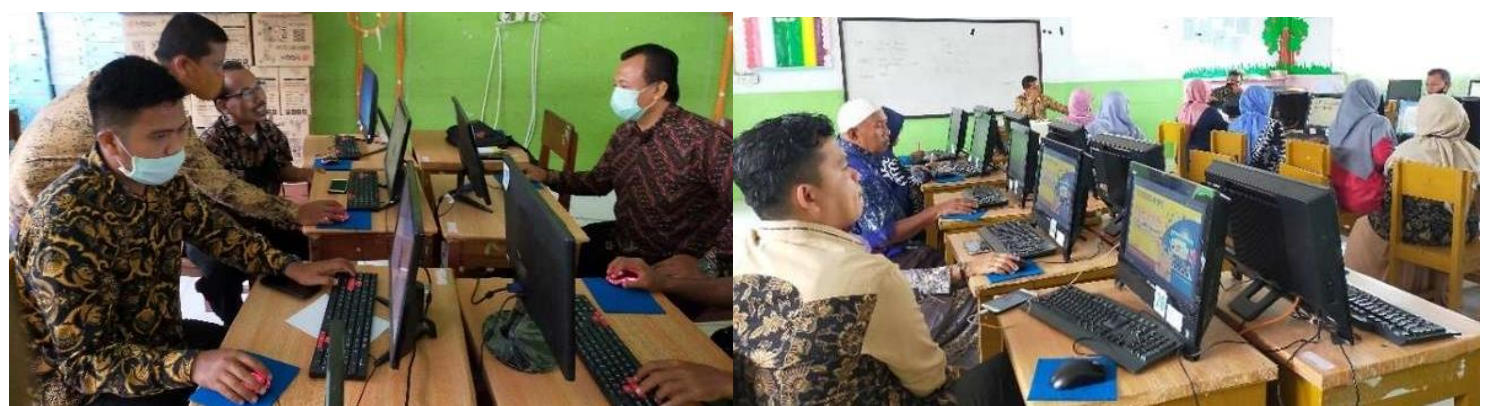

Gambar 6. Praktik kerja perancangan media pembelajaran dengan Ms. Powerpoint 2013

Dari hasil pengamatan saat praktik kerja individu diperoleh bahwa guru-guru (1) antusias bertanya saat mengalami kesulitan dalam mengidentifikasi perangkat dan sumber materi yang akan digunakan dalam media pembelajaran, dan (2) antusias mendesain media pembelajaran terintegrasi TIK menggunakan aplikasi Ms. Powerpoint,

- Hasil project praktik kerja pelatihan perancangan dan pengembangan media pembelajaran terintegrasi TIK pada topik "Klasifikasi Mahluk Hidup" dapat dilihat pada gambar 6 berikut :

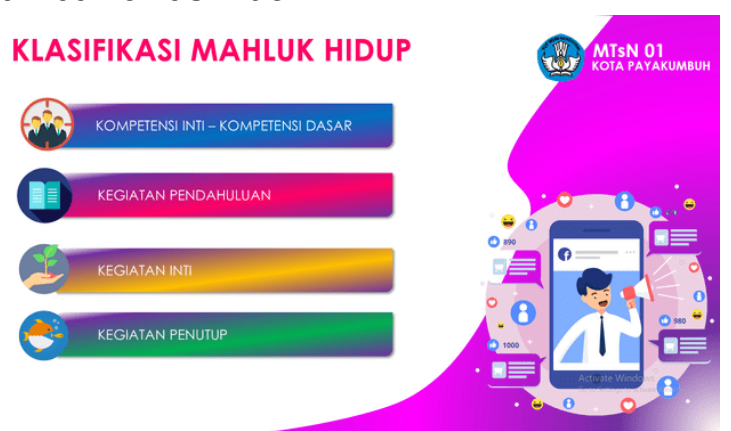

(a) Menu utama (Hyperlink)

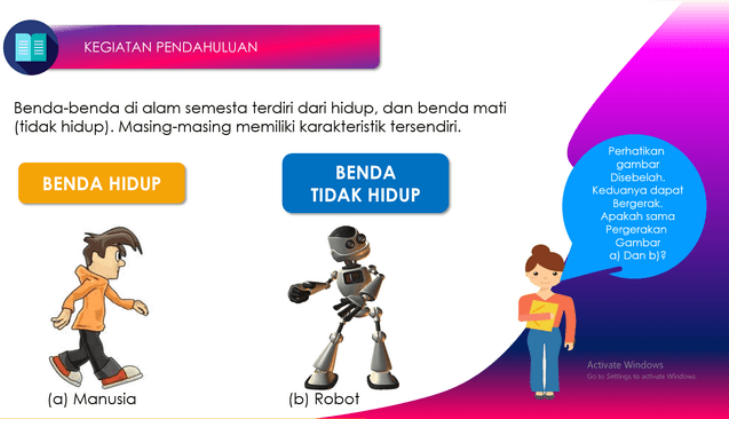

(c) Pendahuluan

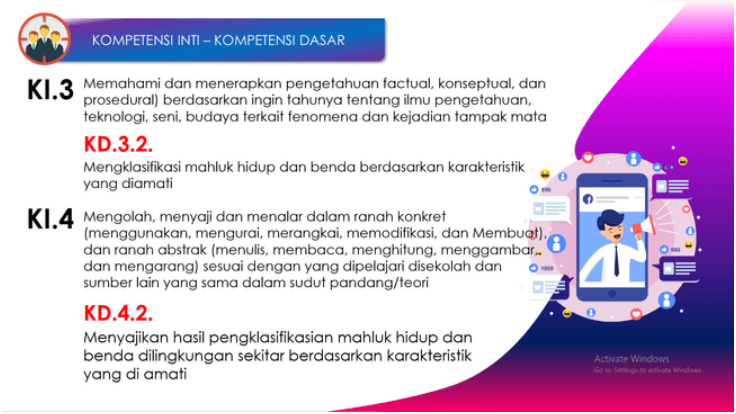

(b) $\mathrm{KI} / \mathrm{KD}$

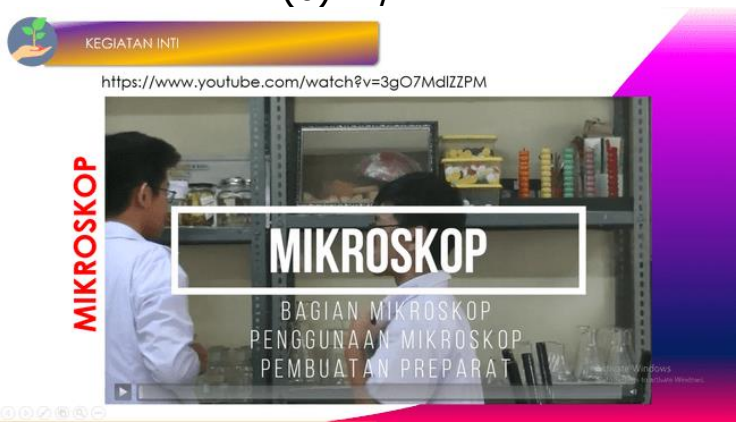

(d) Kegiatan inti 


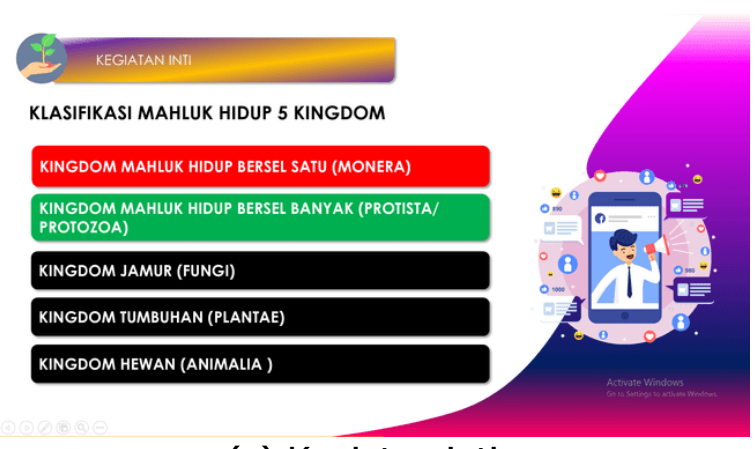

(e) Kegiatan inti

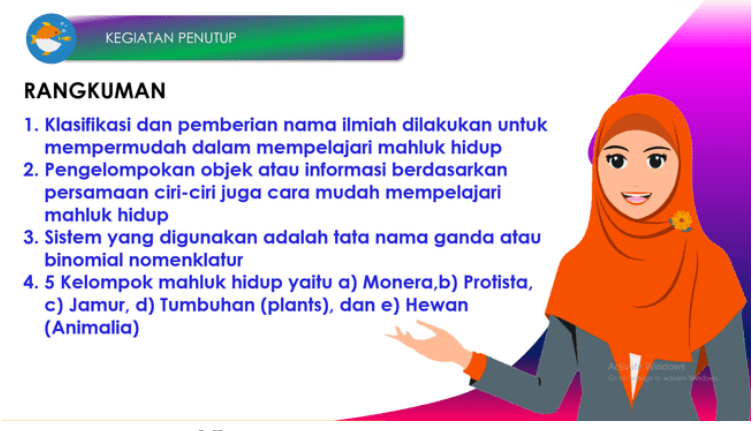

(f) Kegiatan penutup

Gambar 6. Hasil praktik kerja media pembelajaran terintegrasi TIK

Gambar 6 menunjukkan, bahwa media pembelajaran yang dirancang sudah memenuhi standar kualitas media pembelajaran, karena dibuat secara terstruktur, memuat mode representasi pesan ajar dengan multimedia, mudah dibaca, jelas, animasi sesuai dengan tujuan, memiliki hyperlink, dan memiliki unsur kreatif dan inovatif. Disamping itu media yang dirancang juga menggunakan 2 pendekatan yaitu pendekatan idealis (materi mahluk hidup), dan pendekatan software (materi mikroskop).

Setelah guru selesai mendesain media pembelajaran terintegrasi TIK, kemudian tim pengabdi bertanya kepada guru-guru MTsN, apakah sudah memahami cara mengembangkan media pembelajaran terintegrasi TIK?. Guru-guru menjawab bahwa mereka sudah dapat memahami cara merancang media pembelajaran terintegrasi TIK dan guru-guru mengatakan bahwa dengan menggunakan media ajar terintegrasi TIK akan memudahkan guru dalam menyiapkan materi pembelajaran. Dengan menggunakan pendekatan idealis dalam perancangan media pembelajaran dapat menciptakan lingkungan pembelajaran yang aktif, inovatif, kreatif, efektif dan menyenangkan. Dengan menerapkan pendekatan software, akan membantu siswa belajar secara mandiri. Sehingga dapat menjawab permasalahan dibidang pendididkan.

Pernyataan guru-guru tersebut diatas sesuai dengan pendapat (Lungit Wicaksono, 2020), bahwa pemanfaatan TIK dalam pendidikan dapat menjawab permasalahan pendidikan terutama akses dan pemerataan serta mutu pendidikan. Selain memudahkan guru menyiapkan materi pembelajaran, juga sangat membantu dalam menciptakan lingkungan pembelajaran yang aktif, inovatif, kreatif, efektif dan menyenangkan (PAIKEM)(Widiara, 2018). Media pembelajaran mampu meningkatkan motivasi belajar (Kuswanto \& Radiansah, 2018) dan memudahkan peserta didik melakukan pembelajaran mandiri dengan perangkat TIK yang dimilikinya tanpa ruang dan waktu(Asmara, 2015),(Sudratjat, 2020). Menurut (Muslih, 2016) media pembelajaran berbasis TIK dapat meningkatkan kualitas pemahaman peserta didik dalam proses belajar, dan diharapkan dapat meningkatkan prestasi belajar peserta didik.

3. Evaluasi

Setelah kegiatan praktik dan presentasi selesai, guru-guru diminta untuk mengisi angket evaluasi pengabdian yang dikembangkan oleh pengabdi sendiri. Dari hasil angket diperoleh rata-rata skor pengisian angket adalah 86,72 dan standar deviasinya adalah 4,66. Dengan menggunakan rata-rata dan standar deviasi, maka diperoleh kategori sikap terhadap pelatihan pembelajaran peta konsep yang dapat dilihat dalam Tabel 2 . 
Tabel 2. Kategori respon guru terhadap pelatihan

\begin{tabular}{ll}
\hline Nilai & Kategori \\
\hline $93.33 \geq x \geq 90$ & Sangat baik \\
$90>x \geq 86,67$ & Baik \\
$86.67>x \geq 80$ & Kurang \\
$x<80$ & Sangat Kurang \\
\hline
\end{tabular}

Berdasarkan Tabel 2 diperoleh bahwa dari 64 guru diperoleh 20 guru berada dalam kategori sangat baik, 14 guru berada dalam kategori baik, 24 guru kurang, dan 6 guru berada dalam kategori sangat kurang. Guru yang berada dalam kategori sangat baik memiliki respon sangat positif terhadap pelatihan ini. Kelebihan pelatihan ini menurut 20 guru tersebut adalah (1) materi sangat bermanfaat, mudah dimengerti, dan sesuai dengan tujuan pelatihan, materi adalah hal yang baru bagi mereka, dan mereka telah bisa merancang media pembelajaran terintegrasi TIK, (2) pemateri menguasai materi pelatihan, (3) tanya jawab dengan pengabdi memudahkan guru dalam menyelesaikan praktik kerja, dan (4) pemateri telah memfasilitasi kerja mandiri secara baik berupa modul dan bahan yang dibutuhkan selama praktik kerja, dan 5) pelatihan perancangan media pembelajaran terintegrasi TIK, jarang didapat.

Guru yang memiliki respon kurang dan sangat kurang menyebutkan (1) Guru mengatakan bahwa perlu diadakan diskusi dan tanya jawab, (2) alokasi waktu penyelesaian media pembelajaran terintegrasi TIK tidak mencukupi, (3) guru merasa kurang paham dengan cara memanfaatkan TIK dalam pelaksanaan proses pembelajaran, (4) pemateri terlalu cepat dalam menyampaikan materi, dan (5) pelatihan hanya menyelesaikan 1 contoh kasus topik pembelajaran saja.

\section{Kesimpulan}

Dari hasil pelatihan diperoleh bahwa, pengetahuan guru tentang cara mengidentifikasi perangkat TIK, identifikasi sumber materi, dan memahami cara merancang media pembelajaran sesuai dengan standar kualitas media pembelajaran. Karena modul sudah diserahkan ke peserta pelatihan, jadi pemateri hanya menyampaikan pokok-pokok materi yang penting saja. Pada saat praktik, itensitas bertanya lebih sering terjadi karena merupakan kompetensi yang paling dibutuhkan guru. Selama praktik dilaksanakan, pemateri beserta tim dosen mendampingi guru-guru dalam menyelesaikan project medianya.

Meskipun antusias peserta pelatihan pada hari pertama dan kedua cukup bagus, tetapi tim pengabdi merasakan pelatihan yang diberikan kepada guru-guru MTsN 1 Kota Payakumbuh masih belum otpimal dan belum mencapai tujuan pelatihan yang sebenarnya yaitu. Oleh sebab itu saran untuk kegiatan pengabdian serupa adalah 1) tim pengabdi harus menyediakan modul praktik kerja sebelum pelatihan dimulai untuk dibaca dan dipahami oleh peserta, 2) RPP harus disediakan oleh masing-masing guru, untuk dianalisa, dan diedit selama praktik kerja, 3) Pelatihan serupa dapat dilakukan pada jenjang SD, SMP, dan SMA/SMK, 4) media pembelajaran yang dirancang harus memenuhi standar kualitas media pembelajaran, 5) untuk mengembangkan kreatifitas dan inovasi guru, sebaiknya guru dikenalkan juga cara membuat presentasi bahan ajar menggunakan aplikasi lain baik secara offline maupun online, 6) alokasi waktu pelatihan perlu ditambah, 
7) perlu dilakukan pretest dan postest sebelum dilakukan pelatihan, dan 8) pengelompokkan peserta pelatihan berdasarkan usia produktif dengan usia tidak produktif sehingga meskipun terdapat beberapa guru yang tidak mengerti cara mengembangkan media pembelajaran terintegrasi TIK, pihak MTsN (Waka Kurikulum) dapat mengarahkan guru-guru tersebut untuk belajar dengan guru produktif yang masih memiliki kreativitas dan motivasi belajar tinggi, sehingga pelatihan tuntas dan tercipta 1 guru bidang studi memiliki 1 RPP terintegrasi TIK

\section{Daftar Pustaka}

Arsyad, S. (2016). Penggunaan Media INformation And Communication Technology (ICT) Untuk Mengitensifkan Pembelajaran Bahasa Inggris Diluar Kelas. Jurnal Wacana, $14(2), 141-156$.

Asmara, A. P. (2015). Pengembangan Media Pembelajaran Berbasis Audio Visual Tentang Pembuatan Koloid. Jurnal IImiah DIDAKTIKA, 15(2), 156-178.

Hudiono, B. (2013). Pengembangan Bahan Ajar Interaktif Berbasis TIK Menggunakan Slideshow Powerpoint by Using Audio Effect Bagi Guru Matematika SMP Pedalaman Kubu Kalimantan Barat. Jurnal Pendidikan Matematika Dan IPA, 4(1), 25-34.

Isma Nastiti Maharani, L. S. (2016). Pelatihan Membuat Media Pembelajaran Berbasis IT Bagi Guru-Guru SMP Daarul Faalah Cisaat Kabupaten Sukabumi. Jurnal Surya: Seri Pengabdian Kepada Masyarakat, 2(1), 113-118.

Koehler, M. J., Mishra, P., \& Cain, W. (2013). What is technological pedagogical content (TPACK)? Journal of Education, 193(February 2014), 13-19.

Kuswanto, J., \& Radiansah, F. (2018). Media Pembelajaran Berbasis Android Pada Mata Pelajaran Sistem Operasi Jaringan Kelas XI. Jurnal Media Infotama, 14(1), 15-20.

Lungit Wicaksono, D. D. P. U. (2020). Pemanfaatan Media Pembelajaran Berbasis ICT Oleh Guru PENJAS Kota Bandar Lampung. Jurnal Kejaora: Jurnal Kesehatan Jasmani Dan Olah Raga, 5(April), 41-49.

Muslih. (2016). Pemanfaatan Media Pembelajaran Berbasis ICT pada Lembaga. Jurnal DIMAS, 16 (November), 215-234.

Nurhayati, A. S. (2018). Pengintegrasian TIK Dalam Pembelajaran.

Nursita, Darsikin, S. (2016). Pengaruh Model Pembelajaran Berbasis Masalah Terhadap Kemampuan Pemecahan Masalah Hukum Newton pada Siswa Kelas X SMA Negeri 4 Palu. Jurnal Pendidikan Fisika Tadulako (JPFT), 3(2), 18-23.

Sholihah, M., \& Yuliati, L. (2016). Peranan TPACK Terhadap Perempuan Menyusun Perangkat Pembelajaran Calon Guru Fisika Dalam Pembelajaran Post-Pack. Jurnal Pendidikan, 2(2006), 144-153.

Sudratjat, R. (2020). Pemanfaatan Media ICT Pembelajaran Pendidikan Pancasila dan Kewarganegaraan Untuk Meningkatkan Kompetensi Kewarganegaraan di SMA 2 Mranggen. Jurnal IImiah CIVIS, IX(1), 40-60.

Widiara, I. K. (2018). Blended Learning Sebagai Alternatif Pembelajaran di Era Digital. PURWADITA, 2(2), 50-56.

Wulandari, M., \& Iriani, A. (2018). Pengembangan Modul Pelatihan Pedagogical Content Knowledge ( PCK ) Dalam Meningkatkan Kompetensi Profesional dan Kompetensi 
Pedagogik Guru Matematika SMP. Kelola Jurnal Manajemen Pendidikan, 2018(2), 177-189. 